\title{
English teachers' attitudes toward their new roles promoted by English-as-an-international-language pedagogy
}

\author{
Muhammad Rahimi ${ }^{1}$ and Maryam Pakzadian ${ }^{2}$ \\ ${ }^{1}$ School of Foreign Languages, Qilu University of Technology, China \\ ${ }^{2}$ English Department, Isfahan Univeristy of Medical Sciences, Iran
}

\begin{abstract}
Teaching English as an International Language (EIL) has gained significant grounds in recent years. However, the successful implementation of EIL pedagogy largely depends on teachers' attitude toward EIL. As such, exploring teachers' attitudes toward principles of EIL pedagogy is of paramount significance. To this end, researchers of the current study examined teachers' attitudes toward their new roles promoted by the principles of EIL pedagogy. Twenty in-service teachers voluntarily attended semi-structured interviews. Four major findings emerged from the content analysis of the collected qualitative data. First, teachers still considered native accent the correct model. Second, participants were not aware of their roles as promoters of intercultural competence, and culture was not a planned part of the curriculum. Third, the teachers were mostly passive consumers of commercial textbooks instead of being critical users of instructional materials. Fourth, the majority of participants were not critical users of teaching methodologies. The implications of our findings for language teacher education in the contexts of EIL are also discussed.
\end{abstract}

Keywords:English-as-an-International-Language pedagogy; Teachers' attitudes; teachers' roles

\section{INTRODUCTION}

Teachers are the core elements in the successful realization of EIL approach to English instruction (McKay, 2002). In order to implement EIL successfully, teachers should first develop positive views toward EIL (Mckay, 2002). However, it is argued that there are still many teachers who are less willing to adopt EIL pedagogy. Jenkins (2007), for example, maintained that language teachers, especially non-native teachers do not embrace favorable attitudes toward EIL. Also, a quick glance at English teacher recruitment pages shows there is still a preference for native speaker teachers. However, the naive/non-native speaker dichotomy originates from political ideology (Phillipson,1992) and is not based on objective criteria (Davies, 2006). Nevertheless, the term persists to be used unthinkingly by some English Language Teaching(ELT) practitioners and the learners throughout the profession (Holliday, 2009). 
Current research into the role of teachers' attitudes toward EIL (e.g., Duong, 2012; Jenkins, 2005; Park \& Kim, 2014; Selvi, 2013; Zacharias, 2014) reported consistent findings that English teachers across EIL contexts prefer speaking standard varieties such as American or British English and hold negative views toward other accented variants of English, considering them a threat for their own professional identity. In order to promote EIL pedagogy and create awareness about native speaker fallacy (Phillipson, 1992), a growing number of valuable studies have been conducted on the legitimacy of World Englishes (Jenkins, 2015; Kirkpatrick, 2015; Matsuda, 2017; McKay \& Brown, 2016). However, majority of these studies have focused on pronunciation issues in EIL pedagogy and ignored the other aspects of EIL pedagogy (i.e., teachers' role). Therefore, there is still need for further research into English teachers' attitudes towards EIL pedagogy, especially towards their new roles promoted by EIL. As teachers' role is of paramount significance in successful implementation of EIL approach, this study aims to explore how teachers perceive and react to EIL approach in relation to their roles in order to provide potential insights into teacher education programs.

\section{LITERATURE REVIEW}

\section{English as an international language (EIL)}

To date, a great deal has been written about principles and practices of English as an international language (EIL) (e.g., Alsagoff et al., 2012; Jenkins, 2000; Matsuda, 2012, 2017; McKay \& Brown, 2016; Sharifian, 2009). Jenkins (2006) defines EIL as English used as a language of communication among speakers with different first languages. Furthermore, Sharifian (2009) emphasized that EIL is not confined to a specific variety of English. He also draws a distinction between EIL and International English by arguing that EIL is the language of international and intercultural relations which "rejects the idea of any particular variety being selected as a Lingua Franca for international communication" (p. 2). Also, Sifakis (2017) acknowledged the differences between EIL, English as a Lingua Franca (ELF), and World Englishes (WE), and defines Global English (GE) as an umbrella term to refer to all types of interaction between people with different mother tongues. ELF is defined as interactions between members of two or more different linguacultures in English, for none of whom English is the mother tongue' (House, 1999, p. 74). According to Mckay (2018), WE emphasizes a pluricentric view of English in which equal respect is granted to all varieties of English. However, EIL differs from both WE and ELF in the use of English for international communication which considers local language needs and social and educational factors, strategic intercultural competence and the fact that EIL should be culturally neutral (Mckay, ibid). In this article, Sharifian's (2009) definition is adopted as he has provided a comprehensive definition for EIL.

In his attempts to describe the spread of English, Kachru (1986, 1992) identified three concentric circles: Inner Circle, the Outer Circle, and the Expanding Circle countries. Inner Circle countries include countries such as the United Kingdom, America, Canada, Australia and New Zealand where English is used as the first language. The Outer Circle are countries where English is used as 
a second language in multilingual settings such as Malaysia, Singapore, India, Nigeria and their English is norm-developing. Finally, the Expanding Circle refers to territories where English is used as a foreign language for international communication such as Japan, China, and South Korea and their English is considered as 'norm-expanding'. Undoubtedly, majority of English users are bilingual or multilingual speakers from the outer and expanding circle countries.

However, Canagarajah (2006, cited in Alsagoff et al., 2012) maintained, 'three Circles' metaphor suggested by Kachru (1986), is no more able to represent WE since in the context of globalization we have to continually shuttle between different varieties of English to ease the communication. Additionally, the focus in the EIL framework is on communication rather than on factors such as speakers' skin color, nationality, and so on, which in the metaphor of 'Circles' served as symbolic indicators of the politicized construct of the native speaker (Brutt-Griffler \& Samimy, 2002, cited in Sharifian, 2009).

Likewise, Widdowson (1998) posited that native-speakerism is outdated and native speakers are no more the sole owners of English language. He posited that English with its many varieties is utilized for a variety of activities in various fields around the globe. Therefore, English is influenced by both its native and non-native speakers (Crystal, 2012). Bayyurt and Sifakis (2017) proposed that tasks and activities should be designed to raise EIL/ELF/GE awareness and help learners make associations between their own local contexts and international realities to reconsider their attitudes towards standard varieties and norms. In EIL paradigm, English language is considered as a means to present one's own concerns and local culture to others around the globe (McKay, 2003). As such, Brown (2007) suggested that "our zeal for spreading English needs to be accompanied by concurrent efforts to value home languages and cultures" (p. 7). According to Sharifian (2018), we should try to bring global and local forces together in a dual process which may be referred to as the glocalization of the language.

\section{Empirical Studies}

Park and Kim's (2014) studied the paradigm shift that the 2008 revised Korea's national curriculum brought into overall Korean ELT culture, context, goals and objectives, instructional methodology, assessment and evaluation, and above all, educators' and learners' attitudes towards English language and its use. The results revealed that the notion of the native speaker that policy makers have is limited to the Inner Circle. Moreover, in-service teachers lacked hands-on communicative, intercultural and management skills to effectively direct 'teamteaching'.

Duong's (2012) investigated the attitudes and beliefs of educators, administrators and teachers about Global English, particularly within several countries in Asia. The data were gathered from four interview participants and through questionnaires completed by 86 respondents. The findings revealed some support for national Glocal English or "situated Englishes", but not for assessment and international communication purposes.

In Turkey, Coskun ( 2011) probed 47 pre-service Turkish English language teachers, attitudes towards accent in EIL contexts. The findings 
revealed that the participants viewed the linguistic norms utilized by native English speakers as an appropriate pedagogical model. However, the study focused mainly on linguistic norms (i.e. accent) and overlooked evaluating the participants' attitudes towards cultural and pragmatic norms.

Bayyurt's (2006) investigated EIL-related cultural norms and explored a small group of Turkish English language teachers' attitudes towards teaching of cultural norms in ELT classes via a semi-structured interview. The participants supported teaching international culture, which emphasizes the significance of exposure to both native and local culture.

\section{Traditional teacher roles}

Teachers typically assume certain responsibilities regardless of the context that teachers work at and the teaching methodology that they adopt. The first role teachers take is the role of an instructor who tries to help students understand the objectives of the lesson and be engaged in learning-rich activities. Teachers typically adjust the difficulty level of the learning tasks and activities and their own use of language with students' proficiency level and clarify critical points for students by using simpler language. Teachers also act as motivators.

Brown (1995) believed that no matter how modern teachers are, they should take some traditional roles which reflect curricular needs like being a needs analyst. Teachers should be continually involved in process of needs analysis to gather information as the basis of educational planning and developing courses. Teachers adapt their teaching based on the needs and wants of learners. Teachers also develop or adapt learning materials based on their ongoing analysis of students' wants and needs. Teachers at the same time are assessors of their students' learning. Harmer (2007) maintained that there are different alternative roles that teachers can play, but they can choose their roles flexibly. In some contexts, learners prefer their teachers to be more of a controller who dictates everything. In some other contexts, teachers act as facilitators. When the teacher is a controller, he is more active and when the teacher is a facilitator, students play a more active role. Mostly, the word controller has negative connotation of being a dictator or transmitter of knowledge. Some experts (e.g., Lee, Ng \& Jacobs, 1998) believed that it is not conductive for teachers to be the center of teaching act. However, there are certain occasions in which teachers play the role of a controller, for example, when they teach new points, or they assess students' prior knowledge (Harmer, 2007). Another role a teacher plays is the role of a prompter who answers students' questions and give hints to students on how to perform a task. The key purpose of being a prompter is providing encouragement for the students (Harmer, 2007). Also, the teacher does the task himself in order to model the activity. Students may also consider the teacher as a resource which provides correct form of knowledge. Even when the students do the task independently, they need the teacher's help and instruction. The aforementioned roles are traditional in the sense that they are based on educational principles which enjoy the support of many practitioners and researchers. Of course, teachers can flexibly alter their roles based on factors such as the age of the learners, their proficiency level, their preferences and styles. Teachers also have some sociocultural 
considerations while taking different roles, and these decisions are culture-bound and based on specific contexts (Hedge, 2000).

\section{Teacher roles in EIL pedagogy}

A valuable growing body of research on English as an International Language (EIL) (e.g., McKay, 2002; Sharifian, 2009; Alsagoff et al., 2012; Matsuda, 2012; Zacharias \& Manara, 2013) has paved the way for the growth of EIL pedagogy. Research demonstrates that, while there is an increasing acceptance of the learners' needs to use English efficiently in communications involving other non-native speakers, teachers regard their role as the custodians of Standard varieties of English (Bayyurt \& Sifakis, 2017). However, according to Kramsch (2014), in the past decade "world has changed to such an extent that language teachers are no longer sure of what they are supposed to teach nor what real world situations they are supposed to prepare their students for" (p. 296). In EIL pedagogy, teachers should assume new roles and the extent to which teachers would adopt such roles will largely depend on to the extent to which teachers develop positive attitudes towards their new roles.

Teachers assume multiple roles depending on many factors, including the context of teaching, their teaching styles and preferences, and their teaching methods (Richards \& Lockhart, 1994). In addition to many desirable teacher roles that are based on sound educational principles, nowadays the emergence of EIL approach requires teachers to assume new roles (Renandya, 2012). Renandya lists new roles for teachers such as promoters of awareness of English varieties, promoters of intercultural competence, promoters of awareness of and respect for multilingualism, critical users of instructional materials that represent the world cultures and World Englishes, and critical users of socially and culturally appropriate teaching methodology. Other scholars (Byram, 1997; Mckay, 2012) have also proposed EIL principles which assign roles to teachers similar to those suggested by Renandya (2012). However, most of the roles that EIL approach assigns to teachers are in conflict with the traditional roles that teachers were assigned. Most of these traditional roles originate from the native-speakerism ideology (Holliday, 2006). Such traditional roles which are considered unfavorable based on the principles of EIL include teachers as a native language model and the promoter of native model of English, representative of native English speaking cultures, the promoter of using native model in teaching English and zero tolerance for code-switching.

In South Korea, Park \& Kim (2014) reported that the teachers and learners still hold negative attitudes toward other varieties of English. Consequently, they have called for promoting awareness of World Englishes and the application of teaching models based on the needs of local learners in EIL. Similarly, Duong (2012) studied the attitudes and beliefs of 86 educators, administrators, and teachers in Vietnam and seven other Asian contexts towards EIL. The majority of participants acknowledged the presence of diversified forms and functions in international settings. However, only a small proportion of the teachers agreed to teach a local variety of English; they considered it ineffective for successful international communication. 
Phan (2016) investigated teachers' attitudes towards possible implications of the current status of ELT in Vietnam. She also explored whether presenting teachers with information about the contemporary changes within the ELT would have an effect on their pedagogical choices. She collected data from 52 participants in Vietnam, including six focus groups and 19 interviews. Participants' responses ranged from a preference for the NS model, NS cultures and native speaker based materials, on the one side, to a desire for integrating other variants of English and cultures into classrooms. The findings revealed that the teachers' lack of understanding of the sociolinguistic aspect of the ELT and students' limited levels of English introduced challenges for integrating varieties of English into classrooms.

Taken together, the success of EIL and teachers' successful performance of new roles promoted by EIL pedagogy requires teachers to develop new professional competencies and positive attitudes toward EIL pedagogy. A number of proposals have been made on how to successfully adopt EIL pedagogy. Kirkpatrick (2004) has proposed that EIL principles be considered at policy making, curriculum development, materials development, and teacher education programme design (see also Galloway \& Rose, 2015; McKay, 2012; Matsuda, 2012). Also, it has been recommended that teachers can develop necessary critical awareness by using supplementary materials (e.g., audio/video clips, mass media, internet, etc.) and by being exposed to cultural and linguistic diversities (Ahn, 2015; Galloway \& Rose, 2015; Matsuda, 2012). However, it may require teachers' dedicated engagement with the key principles of EIL (Bayyurt \& Sifakis, 2017) and adopting a transformative perspective in EIL teacher education for teachers to develop new competencies and positive attitudes in order to adopt EIL pedagogy. A transformative perspective would require teachers to reflect on and consider changing their own established beliefs according to the principles introduced by the new perspective (Sifakis, 2014).

\section{RESEARCH METHOD}

The current study was conducted in central Iran. The participants were 20 in-service teachers (12 females and 8 males) between ages 21 and 38. Their teaching experience ranged between 2 and 10 years. In line with the principle of maximum variation (Dörnyei, 2008), teachers with various teaching and education backgrounds were recruited for this study. Eleven teachers had bachelor degrees in English, 7 were Master of Art holders, and 2 were Doctor of Philosophy students. Teachers had studied at state universities or private universities in their homeland. Ninety percent of the teachers were familiar with at least another foreign language.

The data were collected through semi-structured interviews which were conducted in English. Data were collected regarding teachers' demographic information and their attitudes toward main tenets of EIL pedagogy. Interviews were recorded on audiotapes. Negative case analysis and member checking (see Dörnyei, 2008, for details) were utilized to ensure the soundness of analyses and interpretations. That is, interpretations and reports were sent to participants in order to assure the response validation. Researchers made minor changes on their interpretations of teachers' responses based on the feedback they received from 
teachers. Moreover, peer checking was used to confirm the dependability of the methodology and interpretations. The interview data went through content analysis based on the guidelines for analyzing qualitative data (Berg, 2004). First, the researchers read the participants' verbal and written responses and comments to each question separately, and looked for the patterns in teachers' responses to each question and coded the patterns. During the coding process, the researchers made a list of analytical memos to record their reflections and interpretations on categorization and codification of text data (Bogdan \& Biklen, 2007; Saldana, 2009). In other words, inductive coding of data was utilized to extract the constitutive themes. Constant comparative method (Glaser \& Strauss, 1967) with open, axial, selective coding strategy (Charmaz, 2006) was used to allow categories and the relationships between them to unfold (Harding as cited in Plamberger \& Gingrich, 2014, p. 96).

\section{Research question}

The research question of the present study are "What are in-service English teachers' attitudes towards EIL pedagogy and their new roles as EIL teachers in the context of the Expanding Circle?"

\section{FINDINGS AND CONCLUSION}

\section{Teachers as promoters of awareness of English varieties}

The following themes emerged as teachers' reasons for their positive attitudes towards American or British English and their negative attitudes toward varieties other than American and British English: their personal preferences, royal and prestigious status of American or British English, Standard status of American or British English, and lack of choice for teachers. Our findings indicate that 14 teachers expressed their personal preference for American or British accent. These teachers affirmed that they had exposure to different varieties of English in pronunciation courses, but they were unwilling to use those varieties. They preferred to speak British or American English. One teacher commented: "I think I can distinguish different varieties of non-native English accents, but you know I'm not willing to speak them." Another teacher pointed that: "I don't have any problem with distinguishing and understanding varieties of English, but I prefer to speak English with native speakers' accent." Ten teachers honestly confessed that they consider British or American accent more prestigious than other varieties. One teacher stated: "I prefer to speak British English. I think it sounds royal and prestigious. My students really like it and consider me as a powerful teacher." He added: "I think when you want to speak English you should speak it like the native speakers do." Twelve Teachers considered American or British English as Standard Englishes. One teacher proposed that: "Correct English or standard variety is American or British English. I personally prefer British English, but both are correct." Eight teachers argued that policies and textbooks are predetermined and teachers have no choice. One teacher referred to the role of teacher education programs and work setting in idealizing American accent:

I remember I was always encouraged to use American English in language institutes, and our teachers used it too when I was a student 
myself. I think the US is the most powerful country in the world, and no one can ignore this reality. Course books which are published by American publishers are more available on the market...by macro policies course books are predetermined and you have no other choice. If the book is written by British writers, we should practice British English and the same is correct for American English.

EIL promotes intelligibility rather than native-speaker pronunciations. Three themes emerged from teachers' responses to the question on their tolerance of pronunciation errors in classroom and their reactions to such errors: (a) correction of persistent errors, (b) correction of errors to avoid fossilization, and (c) tolerance of intelligible pronunciations. Thirteen teachers believed that persistent errors must be corrected. One teacher commented: "If students commit the error for the first time, I usually tolerate it. But I try to correct it for the second or third time." Eleven teachers corrected errors to avoid fossilization of pronunciation errors. One participant emphasized deliberate error correction by commenting that "I correct every type of error because they will be fossilized in future." Nine teachers tolerated intelligible errors. One teacher stated:

If the errors do not cause problems for intelligibility, I won't correct them. I will tolerate such errors...I think some teachers try to exaggerate while speaking English. They try to use stress correctly and they seem really funny in such occasions.

Previous research has indicated that educators, administrators, and teachers hold negative attitudes toward other varieties of English (e.g., Duong 2012; Park \& Kim, 2014). Generally, findings of the current research corroborate Park and Kim's (2014) and Duong's (2012) findings.

\section{Teachers as promoters of intercultural competence and awareness of and respect for multiculturalism}

Dogancay-Aktuna and Hardman (2012) propose in today's varied crosscultural EIL context understanding the cultural differences is of more importance for successful communication than mastering the cultural norms and specifics of any particular country or interlocutor.

Findings of the current research indicate 15 teachers were not aware of their role as promoter of intercultural competence. Teachers had not received any training on developing intercultural competence and did not have knowledge and skills to help students develop intercultural competence. When asked about the concept of intercultural competence, teacher A stated: "nobody has told me about it...our courses in teacher training course didn't cover such concepts." Eighteen teachers considered themselves as language educators and ignored their role as decoders or interpreters of cultural content of the materials. For nine teachers, it was difficult to foster intercultural knowledge in the classroom as collecting data about other cultures around the world was difficult and time-consuming. However, teacher B used a very interesting metaphor when trying to highlight the significance of the intercultural knowledge: I think English teachers should be like encyclopedias. They should know about history, geography, culture, politics, art, and many other subjects...you know I myself learn a lot when I teach a material. I try to explain more when misunderstandings happen. 
Corbett (2010) has suggested that teaching intercultural communicative competence requires knowledge, skills and attitudes. He argued that EIL teachers should serve not only the role of a language teacher, but also that of an intercultural teacher.

Findings of the current research indicate teachers had not received any training in their teacher education programs to raise their critical awareness about the cultural content of the teaching materials. Teacher $\mathrm{C}$ commented:

I don't know what I should do to promote intercultural knowledge. I teach materials based on syllabus...I read passages, check new words,...I teach grammar and pronunciation and I never focus on cultural messages...we discuss views in the classroom, but I never focus on so called intercultural learning. I'm a language teacher...I teach English and I am not a sociologist or anthropologist...I do not know who is an intercultural teacher.

Also, 16 teachers believed they were not intercultural teachers and did not have skills to engage the students in activities that could raise their cultural awareness. When asked about intercultural activities, Teacher D commented: $I$ normally follow the activities in the textbook. I have taught many general English courses and used a variety of ELT textbooks. Intercultural activities are not included in ELT textbook, and I am not teaching culture.

Findings of the current research support previous proposals (e.g., Cobett, $2010 ; \mathrm{Li}, 2017)$ that pre- and in-service teachers be provided with training to empower them to help learners develop intercultural competence.

\section{Teachers as critical users of instructional materials}

Previous research reports that teachers attending overseas teacher education programs change their attitudes toward non-native varieties of English due to their exposure to course contents that promote EIL paradigm in which the norm is multilingualism and not native-speakerism (Canagarajah, 2014; Kirkpatrick, 2014). In the current study, participants were asked if they attach any particular culture to English language. Teachers mentioned a number of reasons to include native culture and avoid adding their own or another culture to the learning materials: (a) Students wants, (b) uselessness of information about other cultures except the target culture, and (c) their lack of choice. Teacher E responded that "culture of native people! As our culture is attached to our language...culture of American, British and generally speaking western people...I think so"

Fifteen teachers were also unaware of the role of source or local culture in teaching English. When asked about their idea about inclusion of source culture in teaching curricula, teacher F (a male teacher) described that it was important for him not to teach local culture in the classroom because of students' wants. She asserted: What's the point in teaching our culture in English classes?! Students pay money to learn about English language and culture. They receive knowledge of their own culture in their history and geography courses.

Most teachers (16) considered teaching cultures other than the target culture useless and illogical, albeit they were not sure about teaching international 
culture in their classrooms. Awell experienced teacher said: We usually read about other countries, their cultures, and cuisine in the textbooks, but I never focus on cultural elements. I don't know if it's useful to teach international culture in the class.

Findings of the current research also reveal 14 teachers were mostly passive consumers of commercial course. Teacher I asserted: "I should work! I need to follow institutes' criteria for teaching. It's not a private job and I should follow the preplanned syllabus which is designed based on comprehensive map. Maybe if I had choice, I would choose other materials."

Therefore, EIL teachers should be encouraged to be more active and mindful in selecting and using teaching materials. As such, it is suggested that to raise EIL teachers' awareness of the linguistic and cultural content of the instructional materials, they should see if the materials reflect the cultures of people in international setting. That is, EIL teachers should become more aware of their new role as critical users of textbooks and even textbook writers (also see suggestions by Yuen, 2011 \& Matsuda, 2017).

\section{Teachers as critical users of teaching methodology}

Given the diversified sociocultural contexts in which English is taught today, EIL (English-as-an-international-language) teachers are required to use a socioculturally fitting teaching methodology (Mckay, 2003). According to Ellis (1996), such sociocultural sound teaching methodology should have to be "culturally attuned and accepted" by the local community (p.213). The findings of the current study show teachers support Communicative Language Teaching (CLT). When asked about their teaching methodology, teacher J commented:

I use CLT. My students like CLT based activities as they focus on fluency rather than accuracy...they want to speak! So CLT is communicative and in sync with their needs...My students are eager to know about western culture and they show no resistance... My focus is on their fluency rather than accuracy and my students like my approach to teaching.

Teacher K pointed to her CLT-based teacher roles by asserting that:

I try to facilitate learning. I try to be a friend for my students and all my attention is paid to assist learners to develop positive attitudes toward the English language and culture...I don't have enough knowledge about cultures in international setting, but I try to speak like a native-speaker and develop my students' communicative abilities.

According to Renandya (2012), EIL teachers should be aware of hidden cultural agenda associated with the teaching methods and critically evaluate the appropriacy of the methodology that they adapt. EIL teachers should constantly check the suitability of teaching methods vis-à-vis the values and cultures of the local community. If any resistance is witnessed at any stage of learning, the teacher should reconcile his westernized teaching methodology with the local context by reframing the tasks or replacing them with the ones more in sync with local culture. 


\section{CONCLUSION}

The present study was conducted to investigate teachers' attitudes toward their new roles promoted by EIL approach. The findings of the current study show, although the teacher participants were all non-native speakers of English, they were mostly unaware of core principles of EIL pedagogy and held their traditional roles and negative attitudes towards EIL. Fourteen teachers considered British and American varieties as the only standard and legitimate Englishes. Also 13 teachers highlighted the importance of intelligibility, but in reality they disagreed with teaching of non-native varieties. An ideal teacher for them was a teacher with native-like pronunciation who teaches native pronunciation and the language and culture of Inner Circle countries. These findings corroborate some previous findings (e.g., Park \& Kim, 2014; Phan, 2017; Renandya, 2012) and show the teachers' lack of readiness to assume new roles promoted by EIL approach.

As Kirkpatrick (2004) has rightly put, EIL principles should be taken into account at policy making, curriculum development, materials development, and teacher education program design. The findings of the current study also show that even two Doctor of Philosophy students who were aware of EIL principles were not willing to tolerate non-native pronunciations in their classrooms. Teachers believed that the mission of language teachers is to teach native-like pronunciation and most of the teachers preferred zero tolerance in case of learners' use of non-native pronunciations. This finding contradicts some previous findings (e.g., Reis, 2011; Swan, 2015) that revealed the teachers shuttled from being a firm believer in the native-speaker myth to challenging the theory. It seems those learners' expectations, education policies, curriculum, teacher education, and textbooks do not provide the opportunities for these teachers to develop favorable attitudes to EIL pedagogy. The findings of the current study also indicate that majority of participants were not aware of their role as promoters of intercultural competence. The teachers were mostly passive consumers of commercial course books instead of being critical users of instructional materials and teaching methodologies.

One viable approach to address these issues is to provide opportunities for these teachers to become aware of principles of EIL approach and use supplementary materials to expose their learners to other varieties of English. Students' exposure to and familiarity with world Englishes is necessary, as there is an emerging need to prepare learners for international communication and promote tolerance of non-native local varieties. In light of the findings of the current study, the researchers suggest that the principles of EIL approach be incorporated into English teaching curriculum, teacher education programs, English teaching and testing materials to provide opportunities for teachers to develop positive attitudes towards EIL pedagogy (see also Galloway \& Rose, 2015; McKay, 2012; Matsuda, 2012). A number of studies show that by using supplementary materials (e.g., audio/ video clips, mass media, internet, etc.) and exposing teachers to cultural and linguistic diversities in international settings they can acquire necessary critical awareness (Ahn, 2015; Galloway \& Rose, 2015; Matsuda, 2012). 
EIL teacher education should not aim at modifying teachers' perspectives overnight. Previous research shows that changing teachers' views is an elaborate process that, even with attentive teachers, may require a long time of dedicated engagement with the key principles of EIL (Bayyurt \& Sifakis, 2017). It is significant to consider a transformative perspective in EIL teacher education. It requires participants to face and alter their own established assumptions about a particular issue and consider change on the basis of principles introduced by the new perspective (Sifakis, 2014).

\section{REFERENCES}

Ahn, H. (2015). Awareness of and attitudes to Asian Englishes: A study of English teachers in South Korea. Asian Englishes, 17(2), 132-151.

Alsagoff, L., McKay, S. L., Hu, G., \& Renandya, W. A. (eds.) (2012). Principles and practices for teaching English as an international language. New York \& London: Routledge.

Bayyurt, Y. (2006). Non-native English language teachers' perspective on culture in English as a foreign language classrooms. Teacher Development, 10(2), 233-247.

Bayyurt, Y. \& Sifakis, N. (2017). Foundations of an EIL aware teacher education. In A. Matsuda (Ed.), Preparing Teachers to teach English as an international language (pp. 3-18). Bristol: Multilingual Matter.

Berg, B. L. (2004). Qualitative research methods for the social sciences (5th ed.). Boston: Allyn and Bacon.

Bogdan, R. C., \& Biklen, S. K. (2007). Qualitative research for education: An introduction to theory and methods (5th ed). Boston: Allyn and Bacon.

Brown, H. D. (2007). Principles of language learning and teaching (5th ed.). White Plains, New York: Pearson Education.

Brown, J. D. (1995). The Elements of language curriculum. Boston, MA: Heinle \& Heinle Publishers.

Brutt-Griffler, J., \& Samimy, K. (2002).Transcending the nativeness paradigm. World Englishes, 20(1), 99-106.

Canagarajah, S. (2006). Changing communicative needs, revised assessment objectives: Testing English as an international language. Language Assessment Quarterly, 3(3), 229-242.

Canagarajah, S (2014). In search of a new paradigm for teaching English as an international language. TESOL Journal, 5(4): 767-85.

Charmaz, K. (2006). Constructing grounded theory, a practical guide through qualitative analysis. Thousand Oaks: Sage Publications Ltd.

Corbett, J. (2010). Intercultural language activities. Cambridge: Cambridge University Press. 
Coskun, A. (2011). Future English teachers'attitudes towards EIL pronunciation. Journal of English as an International Language, 6(2), 46-68.

Crystal, D. (2012). A global language. In P. Seargeant, \& J. Swann (eds.), English in the world. Abingdon: Routledge/Open University.

Byram, M. (1997). Teaching and assessing intercultural communicative competence. Clevedon: Multilingual Matters.

Dörnyei, Z. (2001). Motivational strategies in the language classroom. Cambridge: Cambridge University Press.

Dörnyei, Z. (2008). Research methods in applied linguistics. Oxford: Oxford University Press.

Duong, T. H. O. (2012). Global vs. glocal English: Attitudes and conceptions among educators, administrators and teachers in eight Asian countries. In A. Kirkpatrick \& R. Sussex (Eds.), English as an international language in Asia: Implications for language education (pp. 107-35). Dordrecht, the Netherlands: Springer.

Davies, A. (2006). The native speaker in applied linguistics. In A. Davies \& C. Elder (Eds.), Thehandbook of applied linguistics (pp. 431-450). Oxford: Blackwell.

Dogancay-Aktuna, S., \& Hardman, J. (2012). Teacher education for EIL: Working toward a situated meta-praxis. In A. Matsuda (Ed.), Principles and practices of teaching English as an international language (pp. 103118). Bristol, England: Multilingual Matters.

Ellis, G. (1996). How culturally appropriate is the communicative approach? ELT Journal, 50(3), 213-218.

Galloway, N., \& Rose, H. (2015). Introducing global Englishes. London, England: Routledge.

Glaser, B. G., \& Strauss, A. (1967). The discovery of grounded theory: Strategies for qualitative research. Hawthorne, NY: Aldine Transaction.

Harmer, J. (2007). The practice of English language teaching (4th ed.). Harlow: Pearson Education Limited.

Hedge, T. (2000). Teaching and learning in the language classroom. Oxford: Oxford University Press.

Holliday, A. (2005). The struggle to teach English as an international language. Oxford: Oxford University Press.

Holliday, A. (2009). The role of culture in English language teaching: Key challenges. Language and International Communication, 9, 144-155. 
House, J. (1999). Misunderstanding in intercultural communication: Interactions in English as a lingua franca and the myth of mutual intelligibility. In: Gnutzmann C (ed.), Teaching and learning English as a global language (pp.73-89). Tübingen: Stauffenburg.

Jenkins, J. (2000).The phonology of English as an international language. Oxford: Oxford University Press.

Jenkins, J. (2005). Implementing an international approach to English pronunciation: The role of teacher attitudes and identity. TESOL Quarterly, 39(3), 535-43.

Jenkins, J. (2006). Current perspectives on teaching world Englishes and English as a lingua franca. TESOL Quarterly, 40(1), 157-181.

Jenkins, J. (2007). English as a lingua franca: Attitudes and identity. Oxford: Oxford University Press.

Jenkins, J. (2011). Accommodating (to) ELF in the international university. Journal of Pragmatics, 43(4), 926-936.

Jenkins, J. (2015). Global Englishes: A resource book for students. Abingdon: Routledge.

Kachru, B. B. (1986). The alchemy of English: The spread functions and models of non-native Englishes. Oxford: Pergamon.

Kirkpatrick, A. (2004). English as an Asian lingua franca: Implications for research and language teaching. Asian Englishes, 6, 82-91.

Kirkpatrick, A. (2014) Teaching English in Asia in non-Anglo cultural contexts: Principles ofthe 'Lingua Franca Approach'. In R. Marlina, A. R. Giri (eds.) The Pedagogy of English as an International Language: Perspectives from Scholars, Teachers, and Students (pp. 23-34). Cham: Springer International Publishing.

Kirkpatrick, A. (2015). World Englishes and local cultures. In F. Sharifian (Ed.), The Routledgehandbook of language and culture (pp. 460- 470). London: Routledge.

Kramsch, C. (2014). Teaching foreign languages in an era of globalization: Introduction. Modern Language Journal, 98, 296-311.

Lee, C., Ng, M. \& Jacobs, G. M. (1998). Cooperative learning in the thinking classroom. Educational Practice and Theory, 20(1), 59-73.

Li, G. (2017). Preparing culturally and linguistically competent teachers for English as an international language education. TESOL Journal, 8(2), 250276.

Marlina, R., \& Giri, R. (Eds.). (2014). The pedagogy of English as an international language. Dordrecht: Springer. 
Matsuda, A. (2012). Principles and practices of teaching English as an international language. Bristol: Multilingual Matters.

Matsuda, A. (2017). Preparing teachers to teach English as an international language. Bristol: Multilingual Matters.

Matsuda, A., \& Friedrich, P. (2011). English as an international language: A curriculum blueprint. World Englishes, 30(3), 332-344.

McKay, S. L. (2002). Teaching English as an International Language. Oxford: Oxford University Press.

McKay, S. L. (2003). Toward an appropriate EIL pedagogy: Re-examining common ELT assumptions. International Journal of Applied Linguistics, 13(1), 1-22.

Mckay, S. L. (2012). Principles of teaching English as an international language. In L. Alsagoff, G. W. Hu, S. L. Mckay \& W. A. Renandya (eds.), Principles and Practices for Teaching English as an International Language (pp.28-46). New York: Routledge.

McKay, S.L. (2018). English as an international language: What it is and what it means for pedagogy. RELC Journal, 49(1) 9-23.

McKay, S.L., \& Brown, J.D. (2016). Teaching and assessing EIL in local contexts around the world. New York: Routledge.

Park, J. K., \& Kim, M. K. (2014). Teaching and learning of EIL in Korean culture and context. In R. Marlina \& R. A. Giri (Eds.), The pedagogy of English as an international language: Perspectives from scholars, teachers, and students (pp. 47-61). Cham, Switzerland: Springer International.

Parmegiani, A. (2014). The (dis)ownership of English: Language and identity construction among Zulu students at the University of KwaZulu-Natal. International Journal of Bilingual Education and Bilingualism, 17(6), 683694.

Phan, H. L. (2016). English as an International Language (EIL) in Vietnam: A study of Vietnamese ELT teachers' reflections (master's thesis). Retrieved from https://figshare.com/articles/English_as_an_International_Language_EIL_ in_Vietnam_A_study_of_Vietnamese_ELT_teachers_reflections/4955693

Phan, H. L. (2017). Implications of the changing status of English for instructional models of English: A study of Vietnamese ELT teachers' reflections. TESOL Journal, 9(2), 368-387.

Phillipson, R. (1992). Linguistic imperialism. Oxford: Oxford University Press.

Reis, D. S. (2011). Non-native English-speaking teachers (NNESTs) and professional legitimacy: A sociocultural theoretical perspective on identity 
transformation. International Journal of the Sociology of Language, 2011(208), 139-160.

Renandya, W. A. (2012). Teacher roles in EIL. The European journal of applied Linguistics and TEFL, 1(2), 65-80.

Richards, J. C. \& Lockhart, C. (1994). Reflective teaching in second language classroom. Cambridge: Cambridge University Press.

Saldana, J. (2009). The coding manual for qualitative researchers. Thousand Oaks, CA, : Sage Publications.

Sharifian, F. (ed.) (2009). English as an international language: Perspectives and pedagogical issues. Bristol: Multilingual Matters.

Sharifian, F. (2018). Glocalization of English. In TESOL Encyclopaedia of English Language Teaching. London: Wiley-Blackwell.

Selvi, A. F. (2013). Toward EIL teacher education: Exploring challenges and potentials of MATESOL programmes in the United States. In N. T. Zacharias \& C. Manara (eds.), Contextualizing the pedagogy of English as an international language: Issues and tensions (pp. 43-58). Newcastle upon Tyne, England: Cambridge Scholars Publishing.

Sifakis, N.C. (2014). ELF awareness as an opportunity for change: A transformative perspective for ESOL teacher education. Journal of English as a Lingua Franca, 3(2), 317-335.

Sifakis, N. C. (2017). ELF awareness in English Language Teaching: principles and processes. Applied linguistics, amx034. https://doi.org/10.1093/applin/amx034

Swan, A. (2015). Redefining English language teacher identity. In A. Swan, P. Aboshiha, A. Holliday (eds.), (En)Countering native-speakerism. London: Palgrave Macmillan.

Widdowson, H. G. (1998). The Ownership of English. TESOL Quarterly, 28(2), 377-89.

Yuen, K-M. (2011). The representation of foreign cultures in English textbooks. ELT Journal 65(4): 45-466.

Zacharias, N. T. \& Manara, C. (eds.) (2013).Contextualizing the pedagogy of English as an international language: Issues and tensions. Newcastle upon Tyne: Cambridge Scholars Publishing.

Zacharias, N. T. (2014). Integrating EIL pedagogy in a pre-service teacher program. TEFLIN Journal, 25(2), 217-231. 